\section{Public debates on ethics}

\section{Washington}

BEGINNING in 1991, town meetings may be held throughout the United States to inform the general public about the human genome initiative and to solicit opinions on the ethical, social and legal issues it raises. This is one of the recommendations of the human genome advisory committee's ethics working group, which presented its first report this week at a meeting held by the full committee to discuss the latest five-year plan for the human genome initiative. The new plan does little more than reiterate the goals outlined previously, but the committee stresses with more urgency that completing the project within 15 years, as planned, will require a doubling of the annual budget to $\$ 200$ million within the next two years.

The possible social perils inherent in the human genome programme, such as loss of employment or insurance, are thought to be most likely to occur in the interim phase when genetic diseases can be detected but not treated. By establishing a programme to tackle ethical, legal and social issues long before most of the scientific results start to come in, the two agencies responsible for the initiative, the National Institutes of Health (NIH) and the Department of Energy (DOE), hope to anticipate and avoid problems. Of the budget for human genome research, 3 per cent is being allocated to the study of these social issues.

The ethics working group, chaired by Nancy Wexler of Columbia University, recommends that research into issues such as the ownership and control of genetic information, genetic counselling and the commercialization of results from the human genome initiative should be examined in a series of 'focus groups' which would include representatives of insurance companies, industry, unions, the media and lawyers as well as geneticists and ethicists. With the information thus amassed, the working group would formulate policies to put before the human genome advisory committee. Plans for the first workshop are under way.

The working group also calls for collaboration between NIH and the National Science Foundation to develop educational material on the human genome initiative, aimed at groups such as students, the media, medical practitioners, researchers and recipients of genetic services. It also says there should be postdoctoral fellowships for biomedical researchers who want to study the ethical, legal and social aspects of human genome research; technical education should also be made available to lawyers and ethicists. In all these activities, the working group says the United States should collaborate with other countries, including those that are not directly involved in the human genome initiative. HUGO (the international human genome organization) or UNESCO could coordinate international efforts, the report suggests.

Also before the full advisory committee this week is a proposal to set up a body with responsibility for establishing a national informatics programme. This body, to be called the joint informatics task force, would consist of experts in molecular biology or computer science from academic, government and industrial laboratories and would be responsible for addressing the technical problems of handling the mass of data that the human genome initiative will generate.

The proposal for a joint body comes from the informatics groups of $\mathrm{NIH}$ and the DOE, which would cede their roles to the new body. These groups define the immediate goal of the task force as the creation of a database that provides easy access to current physical mapping, genetic mapping, chromosome mapping and sequencing information. The task force would also be responsible for developing software to support large-scale mapping and sequencing projects. Differ- ent groups will develop their own databases and software, but the aim of a coordinating committee is to avoid "a costly reinvention of the same wheels over and over again at different labs".

The task force will also encourage communication between computer scientists and biologists working on the human genome initiative. The problems that arise from it "will not be solved merely by biologists describing their problems in biological terms and hoping that computer scientists will be able to provide a solution", says the report. Special funding programmes should be established, it says, to provide graduate and postgraduate training in biology to computer scientists and vice versa.

Workshops, short training courses and long-term exchanges of personnel could also improve collaboration.

The more controversial items on the agenda of the new task force would include deciding who should have access to data and how to charge private industry and foundations for access to academic and government databases. It will also examine who will have responsibility for maintaining genomic databases, what level of funding the informatics component of the genome project should have and how to collaborate with the international community.

Christine McGourty

\title{
Changes for science, but for how long?
}

\section{São Paulo}

A YEAR of perplexing reorganization for Brazil's science administration was topped off last week with the re-establishment of the Ministry of Science and Technology by President José Sarney. The ministry had been abolished by Sarney just 11 months earlier. In the meantime, public and congressional protest had led to the reappearance of the ministry as the Special Secretariat for Science and Technology (see Nature 342, 371; 1989). The latest move puts the ministry exactly back where it started at the beginning of the year. The special secretary, Décio Leal de Zagottis, remains at his post but changes his title to "Minister".

"It is a joke in bad taste", was the reaction of Ennio Candotti, president of the Brazilian Society for the Progress of Science (SBPC), who questioned the timing of the change. Brazil will vote to choose a new president this month, meaning that Zagottis will run the new ministry only until 15 March when the new president officially takes office.

The decree that re-establishes the ministry explains that "science and technology matters are vital for the socioeconomic development of the country", and that experience now shows the minis- try is needed. According to the decree, the existence of the ministry will make it easier to deal with international institutions and other agencies in Brazil.

But scientists are baffled by the sudden reorganization. Candotti says it is pointless just to change the name to 'Ministry' when it is lack of resources that is the real problem for science in Brazil. The proposed budget will provide only $\$ 100$ million for science in the first half of 1990 although $\$ 400$ million is needed "barely to survive", he says. FINEP, the Agency for Financing Studies and Projects which provides support for both basic research and technological development in industry, is particularly hard hit in the new budget. "The budget for 1990 is ridiculously small", says Luiz Pinguelli Rosa, head of the Federal University of Rio de Janeiro's distinguished graduate school of engineering. He says that scientists are not against the ministry but are astonished by its reappearance so soon before the election.

The constant change and confusion leads many scientists to view Sarney's government as just a succession of administrative disasters. It shows "Sarney's lack of administrative seriousness", said Rogério Cézar de Cerqueira Leite, of the University of Campinas. Ricardo Bonalume Neto 